Bulletin of Pharmaceutical Sciences
Assiut University
Website: http://bpsa.journals.ekb.eg/
e-mail: bullpharm@aun.edu.eg

\title{
PRELIMINARY PHYTOCHEMICAL INVESTIGATION AND IN-VITRO ANTIDIABETIC ACTIVITY OF AN AYURVEDIC FORMULATION
}

\author{
S. Gayatri ${ }^{1 *}$ and V. Angel Seslin Monica ${ }^{2}$ \\ ${ }^{1}$ Assistant Professor, Sri Ramachandra Faculty of Pharmacy, SRIHER (DU), Porur, Chennai- \\ 600116, Tamil Nadu, India \\ ${ }^{2}$ Student, Sri Ramachandra Faculty of Pharmacy, SRIHER (DU), Porur, Chennai-600116, \\ Tamil Nadu, India
}

\begin{abstract}
Objective: To carry out the preliminary phytochemical analysis and to perform the in-vitro anti diabetic activity for the ayurvedic poly herbal formulation.

Material and Methods: Preliminary phytochemical analysis was performed as per the standard procedures. In-vitro anti-diabetic activity was done by two methods namely alpha amylase inhibitory assay and alpha glucosidase inhibitory assay by taking acarbose as a standard drug for the ayurvedic formulation. Statistical analysis is carried out by means of graphpad prism software version 6.

Results and conclusion: Preliminary phytochemical analysis showed the presence of alkaloids, glycosides, phytosterols, phenols, flavonoids and terpenoids in the formulation. The poly herbal tablet produced $32.2 \%$ inhibition of alpha amylase activity at a concentration of $125 \mu \mathrm{g} / \mathrm{ml}$ and $80.8 \%$ inhibition of alpha glucosidase activity at a concentration of $62.5 \mu \mathrm{g} / \mathrm{ml}$. The present study shows that the selected ayurvedic poly herbal tablets has an anti-diabetic activity comparable with that of allopathic drug - acarbose tablet.
\end{abstract}

\section{INTRODUCTION}

Diabetes mellitus, a metabolic diseases, in which the blood sugar will be higher for a prolonged period of time. It can occur because of two reasons; insufficient insulin production by pancreas or under utilization of the insulin produced. If not treated, it leads to severe complications affecting various organs of the body ${ }^{1-3}$.

Food is converted into glucose by the liver which is then released into the blood stream. Our body gets energy through the glucose. The regulation of glucose level in the body is done by various hormones, and mainly by insulin produced from pancreas. During diabetes, the body won't be able to regulate the concentration of glucose in the blood and resulting in high blood glucose level.
BGR-34 is a poly herbal drug, jointly developed by scientist of National Botanical Research Institute \& Central Institute of Medicinal and Aromatic Plants along with Council of Scientific and Industrial Research.

The important constituents are Berberis aristata, Pterocarpus marsupium, Gymnema sylvestre, Rubia cordifolia, Trigonellafoenumgraecu and Tinospora cordifolia

BGR-34 is a natural dipeptidyl peptidase 4 (DPP-4) inhibitor. It regulates blood glucose level and also posseses cardio-protective action. It prevents the development of diabetic complications by acting as a powerful antioxidant. CSIR has launched BGR-34 for the treatment of diabetes. As there are number of drugs available in the market, an attempt was made to compare the anti-diabetic activity of the polyherbal drug (BGR-34) with an available allopathic drug in the market. 


\section{MATERIALS AND METHODS}

All the chemicals used for the research are of analytical grade. The enzymes were obtained from Enzyme Bioscience Pvt Ltd, Gujrat and Acarbose tablet was obtained from a local pharmacy.

\section{Analysis of Phytochemical Constituents}

Phytochemicals are the chemicals produced by various parts of the plants. These bioactive constituents of plants are tannins, steroids, phenols, flavonoids, terpenoids, alkaloids, and glycosides. These compounds have various activities such as antimicrobial, anti-diabetic, antibacterial, antioxidant and other therapeutic activity ${ }^{2-5}$.

The phytochemical test for alkaloids, phytosterols, saponins, tannins, mucilage, flavonoids, terpenoids, carbohydrates, proteins, aminoacids and phenols were carried out as per the standard procedures reported ${ }^{3-5}$.

\section{in-vitro anti-diabetic assay \\ $\alpha$-Amylase inhibitory assay}

Alpha-amylase enzyme present in the pancreatic juice and saliva, breaks down large starch molecules (insoluble) into small molecules which can be easily absorbed. $\alpha$ amylase inhibitors act by lowering the levels of postprandial hyperglycemia. The estimation of inhibition of $\alpha$-amylase was done by determining the amount of reducing sugar liberated under the assay conditions, in terms of maltose equivalent i.e, decrease in units of maltose liberated. Dinitrosalicylic acid (DNS) method with slight modification was used for the estimation of maltose equivalent ${ }^{6 \& 7}$.

\section{Procedure}

Test samples [BGR-34 (125, 250, 500, $1000,1250 \mu \mathrm{g} / \mathrm{ml})]$ and allopathic drug Acarbose $(125,250,500,1000,1250 \mu \mathrm{g} / \mathrm{ml})]$ were added to $500 \mu \mathrm{l}$ of sodium phosphate $(0.02 \mathrm{M})$ buffer ( $\mathrm{pH}$ adjusted to 6.9 with $1 \%$ $\mathrm{NaCl}$ ) having $0.5 \mathrm{mg} / \mathrm{ml}$ of $\alpha$-amylase enzyme solution. All the tubes were incubated at $25^{\circ} \mathrm{C}$ for $10 \mathrm{~min}$. Then to each tube, $500 \mu \mathrm{l}$ of $1 \%$ starch solution was added at specified intervals. Incubation was continued for another $10 \mathrm{~min}$. The reaction was arrested by the addition of 1 $\mathrm{ml}$ of 3, 5-dinitro salicylic acid (colouring reagent). This was followed by incubation of the tubes in boiling water bath for 5 mins; cooled to room temperature and diluted with distilled water to get a total of $10 \mathrm{ml}$. The absorbance of the diluted solution was then measured at $540 \mathrm{~nm}$.

$\%$ Inhibition $=$

Absorbance of control - Absorbance of extract Absorbance of control

\section{$\alpha$-Glucosidase inhibitory assay}

$\alpha$-Glucosidase present in the small intestine catalyzes the final stage of digestion of starch and disaccharides which are abundant in human diet. From the terminal, non-reducing 1,4-linked $\alpha$-D glucose residues, glucose is released by $\alpha$-glucosidase. Alpha Glucosidase activity in the biological samples can be directly determined with the aid of $\alpha$ Glucosidase assay kit, without pre-treatment. In this assay, $\alpha$-glucosidase enzyme hydrolyses $p$ nitrophenyl- $\alpha$-D-glucopyranoside into a yellow colored chromogen which absorbs at 505 $\mathrm{nm}^{8 \& 9}$.

\section{Procedure}

The $\alpha$-glucosidase enzyme activity was carried out by incubating $200 \mu 1$ of $\alpha$ glucosidase enzyme solution with $200 \mu \mathrm{l}$ of phosphate buffer (pH-6.9) containing varying concentrations of enzyme inhibitor i.e. sample [BGR-34 (1000, 500, 250, 125, $62.5 \mu \mathrm{g} / \mathrm{ml})]$ and Allopathic drug [acarbose (1000, 500, 250, $125,62.5 \mu \mathrm{g} / \mathrm{ml})]$ at $37^{\circ} \mathrm{C}$ for 60 mins in maltase solution. The reaction was ceased by keeping the mixture in boiling water bath for 2 mins and then cooling. To this mixture, $2 \mathrm{ml}$ of glucose reagent was added and the absorbance was measured at $405 \mathrm{~nm}$.

$\%$ Inhibition $=$

Absorbance of control - Absorbance of extract Absorbance of control

\section{Statistical analysis}

For both the assays, statistical analysis were carried out by means of graphpad prism software ver.6. All the data were expressed as mean \pm SEM triplicates. The mean values were compared using Mann-Whitney U test. 


\section{RESULTS AND DISCUSSION}

Qualitative analysis reveals the presence of alkaloids, glycosides, phytosterols, phenols, flavonoids and terpenoids in BGR-34 tablets, whereas saponins, mucilage, carbohydrates, proteins, aminoacids and tannins were found to be absent.

\section{In-vitro anti-diabetic assay \\ $\alpha$-Amylase inhibitory assay}

BGR-34 produced $32.2 \%$ inhibition of $\alpha$ amylase activity at a concentration of 125 $\mu \mathrm{g} / \mathrm{ml}$ whereas acarbose exhibited only $19.15 \%$ inhibition in the same concentration. When the concentration is increased to $1250 \mu \mathrm{g} / \mathrm{ml}$ BGR34 produced only $61.63 \%$ inhibition whereas acarbose (allopathic drug) exhibited $83.91 \%$ inhibition. The results were depicted in tables 1 $\& 2$ and figure 1.

Table 1: Percentage inhibition of alpha amylase activity produced by the allopathic drug.

\begin{tabular}{|c|c|c|c|c||}
\hline $\begin{array}{c}\text { S. } \\
\text { No }\end{array}$ & $\begin{array}{c}\text { Concentration } \\
(\mu \mathrm{g} / \mathrm{ml})\end{array}$ & $\begin{array}{c}\text { Percentage } \\
\text { inhibition }\end{array}$ & SD & SEM \\
\hline 1. & 125 & 19.15 & 2.0 & 1.20 \\
\hline 2. & 250 & 44.37 & 1.37 & 0.79 \\
\hline 3. & 500 & 54.55 & 0.84 & 0.49 \\
\hline 4. & 1000 & 82.41 & 2.89 & 1.67 \\
\hline 5. & 1250 & 83.91 & 2.63 & 1.52 \\
\hline
\end{tabular}

Table 2: Percentage inhibition of alpha amylase activity produced by the poly herbal tablet.

\begin{tabular}{|c|c|c|c|c|}
\hline $\begin{array}{c}\text { S. } \\
\text { No }\end{array}$ & $\begin{array}{c}\text { Concentration } \\
(\mu \mathrm{g} / \mathrm{ml})\end{array}$ & $\begin{array}{c}\text { Percentage } \\
\text { inhibition }\end{array}$ & SD & SEM \\
\hline 1. & 125 & 32.25 & 3.43 & 1.98 \\
\hline 2. & 250 & 42.23 & 1.75 & 1.01 \\
\hline 3. & 500 & 50.80 & 2.67 & 1.54 \\
\hline 4. & 1000 & 57.44 & 0.15 & 0.09 \\
\hline 5. & 1250 & 61.63 & 1.24 & 0.72 \\
\hline
\end{tabular}

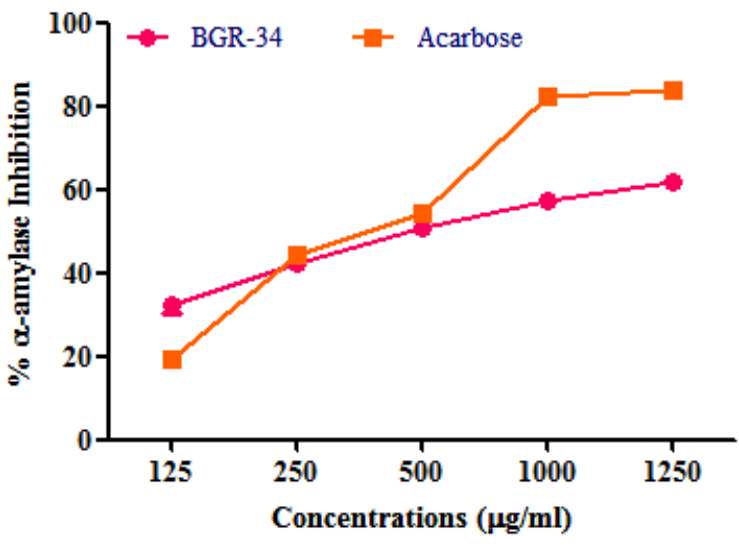

Fig. 1: Comparison of alpha amylase inhibitory activity produced by the allopathic drug and poly herbal tablet.

\section{$\alpha$-Glucosidase inhibitory assay}

From the graph it was observed that the BGR-34 produced a dose dependent increase in the percentage inhibition of the alpha glucosidase enzyme activity and is comparable with that of the allopathic drug, acarbose. BGR-34 has shown $80.8 \%$ inhibition of $\alpha$ glucosidase activity at $62.5 \mu \mathrm{g} / \mathrm{ml}$ and $94.49 \%$ at $1000 \mu \mathrm{g} / \mathrm{ml}$, concentrations, respectively. The results were depicted in table $3 \& 4$ and figure 2 .

Table 3: Percentage inhibition of alpha glucosidase activity produced by the allopathic drug.

\begin{tabular}{|c|c|c|c|c|}
\hline $\begin{array}{c}\text { S. } \\
\text { No }\end{array}$ & $\begin{array}{c}\text { Concentration } \\
(\mu \mathrm{g} / \mathrm{ml})\end{array}$ & $\begin{array}{c}\text { Percentage } \\
\text { inhibition }\end{array}$ & SD & SEM \\
\hline 1. & 62.5 & 51.55 & 3.81 & 2.70 \\
\hline 2. & 125 & 63.98 & 2.97 & 2.10 \\
\hline 3. & 250 & 73.73 & 3.39 & 2.40 \\
\hline 4. & 500 & 81.36 & 0.85 & 0.60 \\
\hline 5. & 1000 & 93.22 & 0.85 & 0.60 \\
\hline
\end{tabular}

Table 4: Percentage inhibition of alpha glucosidase activity produced by the poly herbal tablet.

\begin{tabular}{|c|c|c|c|c||}
\hline $\begin{array}{c}\text { S. } \\
\text { No }\end{array}$ & $\begin{array}{c}\text { Concentration } \\
(\mu \mathrm{g} / \mathrm{ml})\end{array}$ & $\begin{array}{c}\text { Percentage } \\
\text { inhibition }\end{array}$ & SD & SEM \\
\hline 1. & 62.5 & 80.08 & 4.66 & 3.29 \\
\hline 2. & 125 & 86.44 & 0.84 & 0.59 \\
\hline 3. & 250 & 87.71 & 0.42 & 0.29 \\
\hline 4. & 500 & 90.25 & 1.27 & 0.89 \\
\hline 5. & 1000 & 94.49 & 2.11 & 1.49 \\
\hline
\end{tabular}




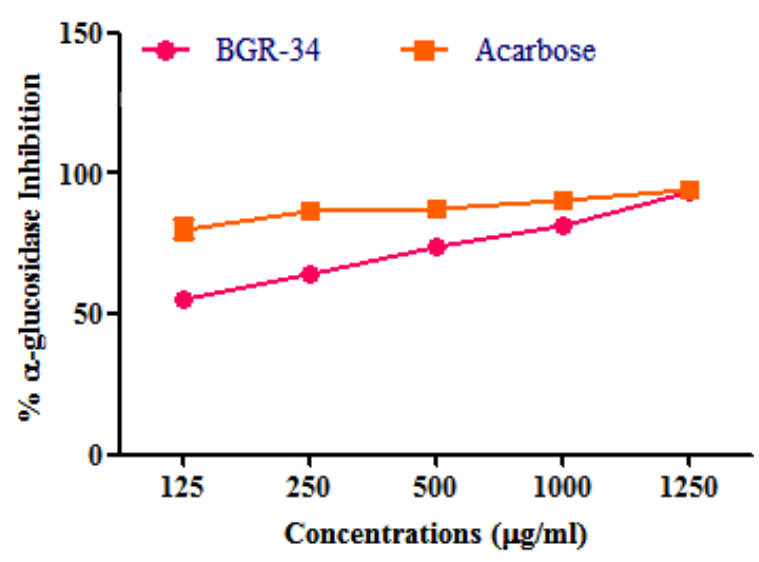

Fig. 2: Comparison of alpha glucosidase inhibitory activity produced by the allopathic drug and poly herbal tablet.

In carbohydrate metabolism the key enzymes present in the small intestine are the pancreatic alphaglucosidase and alphaamylase which convert the consumed polysaccharide to monosaccharide. This action by the enzyme causes postprandial blood glucose level elevation due to the absorption of glucose formed in the small intestine. Drugs that have inhibitory activity on both these enzymes possesses ability to control the postprandial blood glucose level in type 2 diabetic patients. The available drugs in this category are acarbose and miglitol. Our present study clearly demonstrates that BGR-34 possess pancreatic alphaglucosidase and alphaamylase inhibition which confirms that the anti-diabetic action of BGR-34 may act through this pathway by inhibiting the above two enzymes. The safety and efficacy of BGR-34 is further supported by the clinical studies on human beings ${ }^{10}$.

\section{Conclusion}

The present study shows that the selected ayurvedic polyherbal formulation BGR-34 tablets exhibited anti-diabetic activity comparable to that of Allopathic drug (Acarbose tablet) by $\alpha$-amylase and $\alpha$ glucosidase inhibitory assay method. This may be due to the presence of different components in the polyherbal formulation which acts through various pathways.

\section{Ackowledgement}

The authors profusely thank the management of Sri Ramachandra Institute of
Higher Education and Research for providing necessary facilities to carry out the research work.

\section{REFERENCES}

1- A. T. Kharroubi and H. M. Darwish, "Diabetes mellitus: The epidemic of the century", World J. Diabetes, 6, 850 (2015).

2- The Ayurvedic Pharmacopoeia of India, $1^{\text {st }}$ Edn., New Delhi: Department of AYUSH, Ministry of Health and Family Welfare (2001).

3- Indian Pharmacopoeia, Government of India, Ministry of Health and Family Welfare, Controller of Publications, Vol. 1 (2007).

4- C. K. Kokate, A. P. Purohit and S. B. Gokhale, "Practical Pharmacognosy", Vallabh Prakashan, New Delhi (2004).

5- S. H. Ansari, "Essentials of Pharnacognosy", Birla publications, New Delhi (2006).

6- A. Sathiavelu, S. Sangeetha, R. Archit and S. Mythili, "In-vitro anti-diabetic activity of aqueous extract of the medicinal plants Nigella sativa, Eugenia jambolana, Andrographis paniculata and Gymnema sylvestre", Int. J. Drug Dev. \& Res., 5, 323 (2013).

7- M. I. Kazeem, J. O. Adamson and I. A. Ogunwande, "Modes of inhibition of $\alpha$ amylase and $\alpha$-glucosidase by aqueous extract of Morinda lucida Benth Leaf", BioMed Res. Int., Article ID 527570 (2013).

8- A. Rajendran, R. Sudeshraj and S. Sureshkuma, "Potential antidiabetic activity of medicinal plants", The Journal of Phytopharmacology, 7, 456 (2018).

9- A. Widiyanto, E. Anwar and T. Nurhayati, "Anatomical study and characterization of metabolites in leaves of Momordica charantia L.", Pharmacog. J., 10, 907 (2018).

10- B. P. Gupta, I. Sharma, N. Kohli, S. Sharma, A. Rathi and A. K. Sharma, "Preliminary clinical assessment and nontoxicity evaluation of an ayurvedic formulation BGR-34 in NIDDM", Journal of Traditional and Complementary Medicine, 8, 506 (2018). 


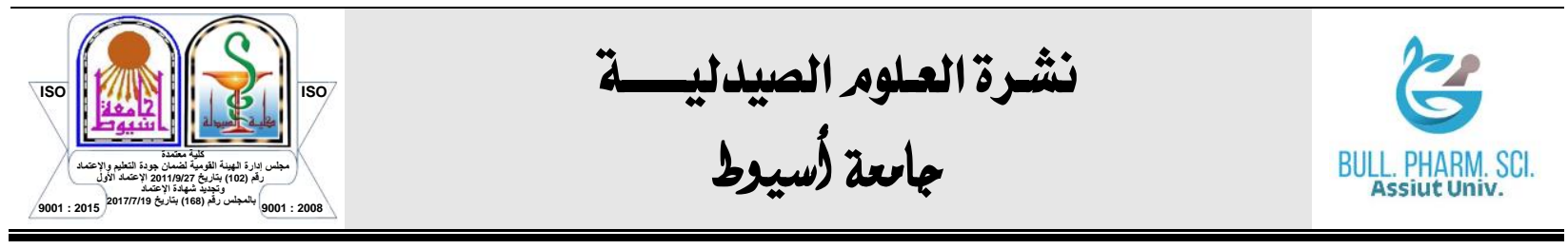

\section{المسح الكيميائي الأولى ودراسة النشاط المضاد لمرض السكري خارج

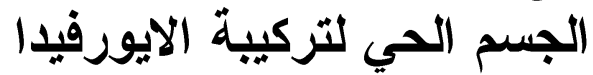

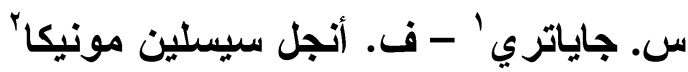

'أستاذ مساعد ، كلية الصيدلة السري راماتشاندرا ، سريير (دو) ، بورور ، تشيناي - 11 | . .7 ، تاميـل نـادو ، الهند

'طالبة ، كلية الصيدلة في سري راماشاندرا ، سريير (دو) ، بورور ، تشيناي -7 | | ـ .7 ، تاميل نادو ، الهند

الههف: إجر اء التحليل الكيميائي الأولي و إجراء النشاط المضاد لمرض السكري خارج لجســم الحـي ألـي لتركيبة الايورفيدا و المكونة من أعشاب متعددة.

المواد والطرق: تم إجر اء التحليل الكيميائي الأولي وفةًا للتجارب القياسية. تم إجر اء النشــاط المضــاد

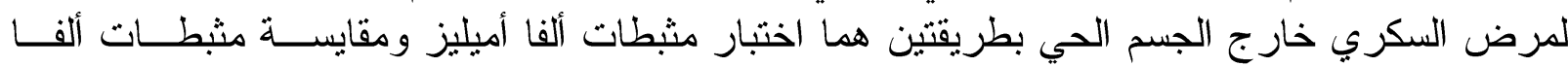

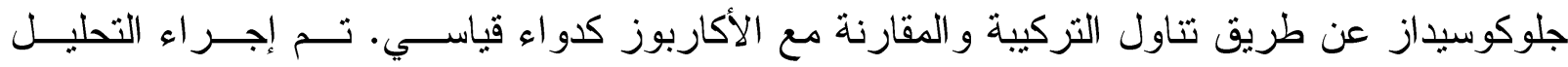

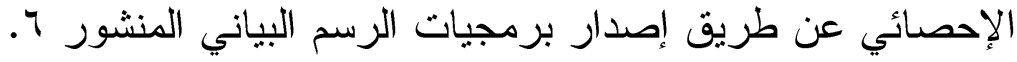

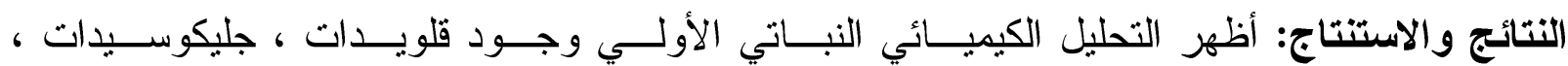

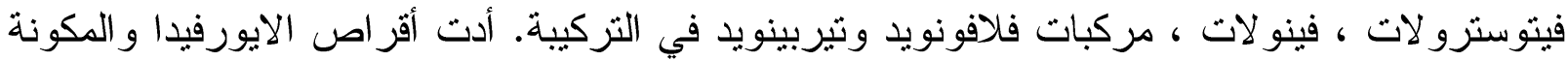

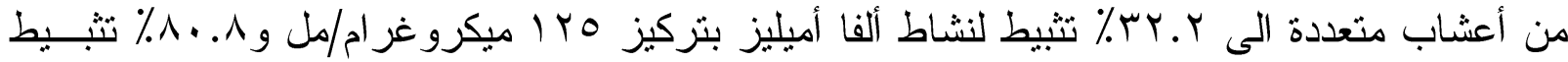

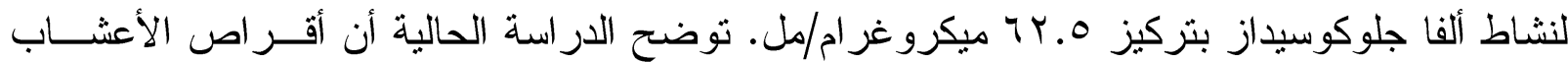

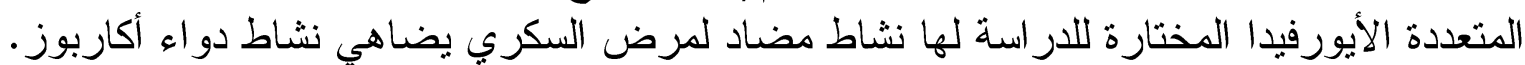

